\title{
Effect of noise pollution on male fertility (Review)
}

\author{
Nadri F, MSc ${ }^{1}$, Khavanin A, $\mathrm{PhD}^{2 *}$, Mazaheri Z, $\mathrm{PhD}^{3}$, Soleimanian A, $\mathrm{MSc}^{4}$ \\ 1- PhD Student of Occupational Health Engineering, Dept. of Occupational Health, Faculty of Medical Sciences, Tarbiat \\ Modares University, Tehran, Iran. 2- Associate Prof., Dept. of Occupational Health, Faculty of Medical Sciences, Tarbiat \\ Modares University, Tehran, Iran. 3- Assistant Prof., Dept. of Anatomical Sciences, Faculty of Medical Sciences, Tarbiat \\ Modares University, Tehran, Iran. 4- MSc in Occupational Health Engineering, Dept. of Occupational Health, Faculty of \\ Medical Sciences, Tarbiat Modares University, Tehran, Iran.
}

\begin{abstract}
Received: November 2016, Accepted: December 2016

Background: Noise as a most common harmful physical agent in workplaces has some effects on the exposed persons such as hearing threshold reduction, increasing blood pressure, and interference with the speech. The adverse side-effect of noise is one of the scientific areas that have seldom been considered by researchers. The aim of this study was to investigate the effects of occupational noise on the male fertility (human and experimental animals) to be finally able to provide solutions for the future orientation of research studies, and on the other hand, to increase awareness in industrial divisions about effects of noise stress on workers fertility.

Materials and Methods: In this study, we conducted the bibliographic search in PubMed and Google Scholar databases and studies about effects of workplaces noise on the male fertility with keywords such as fertility, noise, and testicular damage were selected.

Results: Male infertility is a major health problem in the world. According to different study, Noise can impact on testis weight, sperm parameters (count, viability, motility and morphology), sexual hormones, testicular tissue, oxidative stress and finally infertility.

Conclusions: The results of this study shows that noise exposure plays an important role as an environmental risk factor for male fertility; therefore, it is necessary to formulate guidelines for occupational exposure limits of noise effects, exposure time, use or not usage of supplemental antioxidants and to consider fertility and not be confined merely to the effects of noise on hearing system.
\end{abstract}

Keywords: Noise, Fertility, Workplaces.

\section{Introduction}

Public health experts believe that environmental risks account for $24 \%$ of the disease burden. Widespread exposure to environmental noise caused by transport (road, rail and airports) and industrial units have contributed greatly to the burden of disease. One in three people suffers from traffic noise and one out of every five people suffers from sleep disorders due to traffic noise, so the noise is considered a threat to public health. Years of life lost due to disability (DALY) caused by environmental noise in Western Europe countries includes 61,000 years for ischemic heart disease, 45,000 years for cognitive impairments in children, 903,000 years for sleep disorders, 22,000 years for tinnitus and 654,000 years for annoyance and inconvenience. If all the above cases are summed up, a total of 1.6 million disabilities are caused by environmental noise, which suggests that at least a million years are lost in these countries annually due to traffic noise(1). In the twenty-first century, noise exposure is known as one of the threats to public health. Despite sufficient evidence on the impact of noise on reducing hearing threshold, high blood pressure, annoyance, sleep disturbance and decreased performance, there is still little documentation on the impact of noise on the

\footnotetext{
Corresponding author: Ali Khavanin, Dept. of Occupational Health, Faculty of Medical Sciences, Tarbiat Modares University, Tehran, Iran. E-mail: khavanin@Modares.ac.ir
} 
fertility rate (2). Noise as an environmental stressor, has an impact on the reproductive system, reduced fertility and fetus health (3). It suppresses testosterone synthesis in the testicles (4). The pathological effects of highfrequency noise exposure on organs including brain, heart, liver and spleen have been examined, and it has been shown that noise can cause damage of varying degrees in these organs(5). The present study attempted to examine the effects of noise pollution on male fertility by searching available documents.

\section{Methods}

This review article has been developed to assess the effect of noise pollution on male fertility with industrial health approach. According to information obtained by the research team, this is the first research on the effect of occupational noise exposure on male fertility with an industrial health approach. The study has been collected by searching articles available on Google Scholar and PubMed databases and selected keywords, including "fertility", "noise" and "testicular damage". Studies on occupational noise effects on male fertility have been entered into the study.

\section{Discussion}

Noise is one of the harmful environmental factors and an inevitable phenomenon in home and workplace (6). There are a variety of environmental noise sources such as transport, industry, construction, society-based sources (neighbors, radio, television, restaurants) and leisure-based sources (portable music producers, toys, concerts, etc.) (1). It is estimated that 22.4 million workers in the United States are exposed to noise levels higher than the standard threshold (85 $\mathrm{dB})(7)$ and more than 100 million people are exposed to harmful environmental noise caused by traffic and other sources of audio equipment(8). Based on studies conducted in Iran, agriculture $(9,10)$, and cement industry workers(11) and are exposed to noise levels higher than the standard. In Iran, more than 2 million workers in industry and service units are exposed to potentially dangerous levels of noise (above $85 \mathrm{~dB}$ ) (12). Noise is one of the occupational stressors that have not been well studied. People, especially young people and pregnant women should be aware of the dangers of exposure to high levels of noise, particularly the impact on reproduction (13).

\section{Physiology of male reproductive system:}

Testis is the main reproductive organ with endocrine function in the male sex (14). Spermatogenesis is a complex process that consists of several successive and regular stages, during which the division and differentiation of spermatogonial stem cells occur, which in turn results in the production of sperm. This complex process that occurs in the seminiferous epithelium of the mammalian testis, starts from the time of puberty and persists throughout life. There are $10^{8}$ cells in human testis, 20,000 cells of which are stem cells. The amount of time a stem cell needs to differentiate into a sperm is different in various species (15). Spermatozoa is a cell composed of three parts, including head, body and tail, which may be different in different species and these differences are mostly related to the head and length of the sperm(16). Sperm length is between 60 to 70 $\mu \mathrm{m}$ in humans (17). Human sperm production depends on the temperature of the testis, which is normally lower than core body temperature. The impact of daily activities on the temperature of the testis is not well understood (18). Testosterone is the main androgen of testes that is composed of acetate and cholesterol produced in Leydig cells. In men, 4 to $10 \mathrm{mg}$ testosterone is secreted daily (19). Figure 1 shows hypothalamic-pituitarytesticular axis in males. 


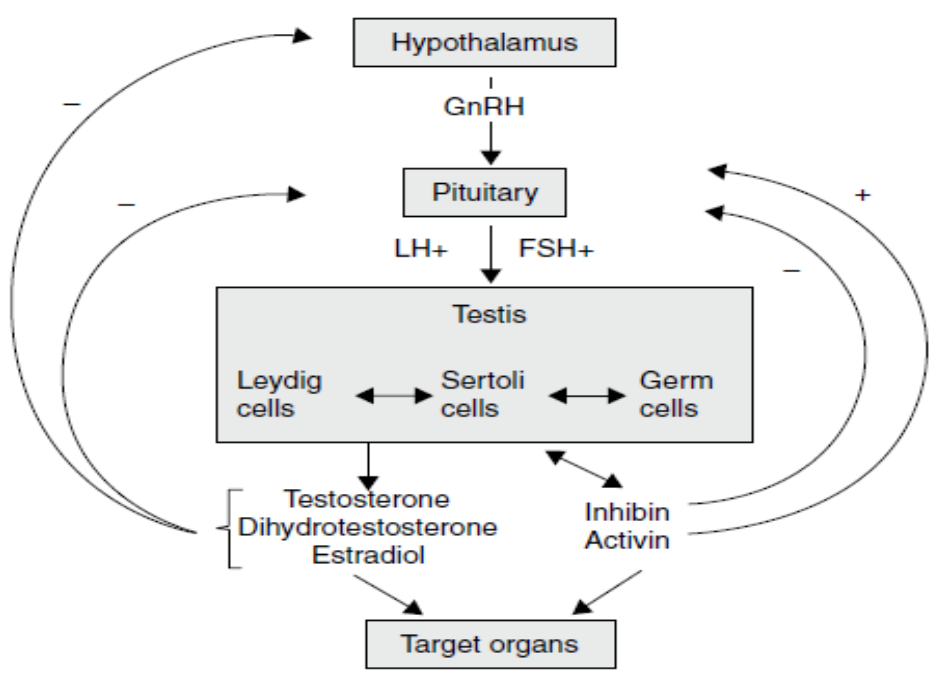

Figure 1: Diagram of the hypothalamic-pituitary-testis axis(20)

As shown in figure 1, LH, FSH and testosterone are involved in spermatogenesis. The reproductive parameters in different species are different compared to the human (Table 1) (15).

Table 1: Differences in reproductive parameters in various species

\begin{tabular}{|c|c|c|c|c|c|}
\hline Parameter & & Mouse & Rat & Monkey & Human \\
\hline $\begin{array}{c}\text { Duration of cycle of } \\
\text { seminiferous epithelium (day) }\end{array}$ & & 8.6 & 12.9 & 9.5 & 16 \\
\hline $\begin{array}{c}\text { Duration of spermatogenesis } \\
\text { (day) }\end{array}$ & & 35 & 52 & 38 & 74 \\
\hline Testes weight $(\mathrm{g})$ & & 0.2 & 2.6 & 49 & 34 \\
\hline Daily sperm production & Per gram testis, $10^{6} / \mathrm{g}$ & 28 & 18 & 23 & 4.4 \\
\hline & Per male, $10^{6}$ & 5 & 48 & 1100 & 125 \\
\hline Sperm reserves in cauda, $10^{6}$ & & 49 & 440 & 5700 & 420 \\
\hline Epididymal transit time (day) & & 5 & 7.2 & 10.5 & 5.5 \\
\hline
\end{tabular}

Studies on fertility (sperm analysis) to assess the quality of sperm parameters (count, motility, viability and morphology), and human testicular tissue changes require special ethical considerations. As shown in table 1, duration of cycle of seminiferous tubules epithelium, spermatogenesis period, the amount of sperm stored in the epididymal cauda region and epididymal transit time in rats are closer to humans than other species. Low cost, availability, portability, relatively docile nature and high reproduction rate are other advantages of this species.

Infertility: At the global level, infertility is defined as inability of a couple to become pregnant after unprotected sexual intercourse for 12 months or more (21). Today, male infertility is a major health problem (22). Vaziri et al. showed that there is no significant relationship between the mean count and sperm morphology in different occupational groups (23). Kamali et al. showed that male and couple factors account for $50.5 \%$ and $11.6 \%$ of infertility rates respectively. Infertility is associated with consequences such as stress, depression, anxiety, family crisis and divorce. Infertile couples incur high costs in hopes of bearing a child (24). Ghahremani and Ghaem showed that about half of infertility cases are related to male factors (25). Another study showed that female, male and couple factors account for $40 \%-50 \%, \quad 30 \%-40 \%$ and $10 \%-30 \%$ of infertility rates respectively. Male infertility 
may be caused by congenital abnormalities or environmental factors (8). Vahidi et al. showed that $25 \%$ of couples have experienced early infertility(26). In 2002, the World Health Organization estimated that there were about 186 million infertile women (after one year of marriage) in developed countries (excluding China) (27). Based on available statistics, infertility and its associated problems are seen in $35 \%$ of couples, with insufficient number of healthy and active sperms in men being one of its most common causes (28). Male infertility depends on sperm factors such as reduced count and reduced motility. Abnormal sperm morphology, hormonal deficiencies and genetic causes are also effective in male infertility (29). After reviewing 61 papers on seminal concentration and volume, Elizabeth et al. showed a significant decrease had occurred in sperm count (from 113 to 66 million per $\mathrm{ml}$ ) from 1940 to 1990 . Also, the seminal volume had dropped from 3.40 to 2.75 $\mathrm{ml}$ in the same period (30). It has been estimated that $8 \%$ to $12 \%$ of couples are affected by infertility around the world (31). 30 to 45 percent of abnormal semen parameters resons have not been identified (32). There is evidence that male fertility is declining worldwide, in which lifestyle and environmental factors can play a key role (33).

Effects of noise stress on fertility: The mechanism of noise effect on this process has not been conclusively identified, but most studies have shown that the main cause of decreased sperm production and somehow reduced sperm quality parameters (count, motility, viability and morphology) was decreased testosterone synthesis (Table 2). Testosterone production is strongly affected by nutrition, water limitation and noise stress (34). Pramanik et al. showed that traffic noise exposure $(90-80 \quad \mathrm{~dB})$ decreases testicular weight, protein levels and sperm counts and increases testicular cholesterol levels. Traffic noise changes sperm morphology, increases abnormal sperm production and suppresses production of testosterone (35). Chamkoori et al.'s study showed a significant decrease in concentration of testosterone, LH and FSH and major changes in sperm parameters among workers exposed to noises as loud as $119 \mathrm{~dB}$ (6). Lasheen et al. showed that noise stress led to histopathological changes in testes; it increased the number of apoptosis and reduced the number and size of seminiferous tubules in prenatal and postpartum groups (13). Diab et al.'s study showed Noise exposure causes a showed a moderate reduction in the size seminiferous tubules with focal degenerative, reduced number of spermatogonic cells and diffuse hyperplasia of Leydig cells in the interstitium (36). Jalali et al. demonstrated that weight of epididymis, seminal vesicle and prostate, and sperm count had been significantly reduced in the noise-exposed group compared with the control group and suggested that people's homes and workplaces are required to be built in a safe distance from the noise source (37). Swami et al. demonstrated that noise not only imposed a negative effect on the auditory system, but also affected the performance of other parts of the body such as the level of cortical hormone, adreno-corticosterone, norepinephrine, FSH and LH (3). Ruffoli et al. showed that noise exposure increased fat accumulation in mouse testis and consequently reduced testosterone production (38). Ghanbari et al. showed that noise exposure decreased total antioxidant capacity of sperm and testosterone but there was no effect on sperm parameters. Duration of exposure was 14 days in the current study and it was suggested to select exposures of equal duration to full cycle of spermatogenesis in rats (48-52 days) (39). Vosoughi et al. showed that there was a significant difference between mouses exposed to noise of $100 \mathrm{~dB}$ and the control group in terms of sperm count, percentage of sperm viability and motility. This study was conducted in two different periods of 10 days (full cycle of seminiferous tubular epithelium cells reconstruction in the mouse equivalent of 8.6 days) and 35 days (equivalent to full spermatogenesis cycle in mice). The researchers concluded that sperm parameters and testicular tissue changes can be 
observed after 35 days (40). Saki et al. demonstrated that noise exposure had negative impact on LH, FSH and testosterone and ultimately fertility (41). Abdollahi et al. showed that the percentage of progressive sperm motility, immobile sperm and sperm viability in the noise-exposed group was significantly decreased compared with the control group (42). Table 2 shows summary of articles on noise and fertility, taking into account variables like noise levels, frequency range, exposure time, and laboratory samples.

Table 2: A summary of studies in the field of noise and fertility

\begin{tabular}{|c|c|c|c|c|c|c|c|}
\hline \multirow{2}{*}{$\begin{array}{l}\text { Authors } \\
\text { and year }\end{array}$} & \multirow{2}{*}{$\begin{array}{l}\text { Noise level } \\
\text { (dB) }\end{array}$} & \multirow{2}{*}{$\begin{array}{l}\text { Frequency } \\
\qquad(\mathbf{H z})\end{array}$} & \multicolumn{2}{|c|}{$\begin{array}{l}\text { Exposure } \\
\text { shift }\end{array}$} & \multirow[t]{2}{*}{ Exposure time } & \multirow{2}{*}{$\begin{array}{l}\text { Test } \\
\text { case }\end{array}$} & \multirow[t]{2}{*}{ Key results } \\
\hline & & & Day & Night & & & \\
\hline $\begin{array}{c}\text { Diab et } \\
\text { al(36) } 2012\end{array}$ & 100 & $0-26000$ & $*$ & & $\begin{array}{l}6 \text { hours/day } \\
30 \text { consecutive } \\
\text { days }\end{array}$ & Rat & $\begin{array}{l}\text { A significant decrease in } \\
\text { sexual hormones level/ } \\
\text { Moderate changes in } \\
\text { testicular tissue }\end{array}$ \\
\hline $\begin{array}{l}\text { Lasheen et } \\
\text { al(13) } 2015\end{array}$ & 100 & $0-26000$ & $*$ & & $\begin{array}{l}6 \text { hours/ day } \\
4 \text { week } \\
\text { consecutive }\end{array}$ & Rat & $\begin{array}{l}\text { Reduction of testosterone } \\
\text { biosynthesis/ cholesterol } \\
\text { Accumulation in the testes }\end{array}$ \\
\hline $\begin{array}{l}\text { Fathollahi } \\
\text { et al(43). } \\
2013\end{array}$ & $90-120$ & $300-350$ & & $*$ & $\begin{array}{l}12 \text { hours/night } \\
50 \text { consecutive } \\
\text { night }\end{array}$ & Rat & $\begin{array}{c}\text { Testosterone levels } \\
\text { Suppression in noise } \\
\text { exposed groups and improve } \\
\text { with prescribed vitamins (E, } \\
\mathrm{C} \text { ) }\end{array}$ \\
\hline $\begin{array}{l}\text { Kenani et } \\
\text { al(44). } \\
2015\end{array}$ & $90-120$ & $300-350$ & & $*$ & $\begin{array}{l}12 \text { hours/night } \\
50 \text { consecutive } \\
\text { night }\end{array}$ & Rat & $\begin{array}{l}\text { Increased levels of LH and } \\
\text { FSH/ Abrupt decline in } \\
\text { testosterone levels } \\
\text { compared to control group }\end{array}$ \\
\hline $\begin{array}{l}\text { Mohamed } \\
\text { et al(45). } \\
2015\end{array}$ & 95 & $\begin{array}{l}\text { White } \\
\text { noise }\end{array}$ & $*$ & & $\begin{array}{c}4 \text { hours/day } \\
45 \text { consecutive } \\
\text { day }\end{array}$ & Rat & $\begin{array}{c}\text { Reduction of } \\
\text { Spermatogonial stem cells } \\
\text { in noise exposed groups }\end{array}$ \\
\hline $\begin{array}{l}\text { Ruffoli et } \\
\text { al(38). } \\
2006\end{array}$ & 100 & $0-26000$ & $*$ & & $\begin{array}{l}6 \text { hours/ day } \\
6 \text { week } \\
\text { consecutive }\end{array}$ & Mice & $\begin{array}{l}\text { Testosterone levels } \\
\text { Suppression in noise } \\
\text { exposed groups }\end{array}$ \\
\hline $\begin{array}{l}\text { Jalali et } \\
\text { al(37). } \\
2012\end{array}$ & $90-120$ & $300-350$ & & $*$ & $\begin{array}{l}12 \text { hours/night } \\
50 \text { consecutive } \\
\text { night }\end{array}$ & Rat & $\begin{array}{c}\text { Testicles, epididymis and } \\
\text { seminal vesicles weight loss }\end{array}$ \\
\hline $\begin{array}{l}\text { Swami et } \\
\text { al(3). } 2007\end{array}$ & $\begin{array}{c}100 \\
\text { (traffic } \\
\text { noise) }\end{array}$ & 10000 & $*$ & & $\begin{array}{c}\text { Acute exposure: } \\
1 \text { and } 3 \text { hours } \\
\text { Chronic } \\
\text { Exposure: } \\
1 \text { and } 3 \text { hours per } \\
\text { day for } 60 \text { and } \\
90 \text { consecutive } \\
\text { day }\end{array}$ & Rat & $\begin{array}{c}\text { Reduction in testosterone } \\
\text { level/ permanent effect of } \\
\text { testis histology and sperm } \\
\text { morphology }\end{array}$ \\
\hline $\begin{array}{l}\text { Vosoughi } \\
\text { et al(40). } \\
2012 \\
\end{array}$ & 100 & $700-5700$ & $*$ & & $\begin{array}{l}8 \text { hours/day for } \\
10 \text { consecutive } \\
\text { day }\end{array}$ & Mice & $\begin{array}{l}\text { Reduction in sperm count, } \\
\text { viability and motility }(\%)\end{array}$ \\
\hline $\begin{array}{l}\text { Saki et } \\
\text { al(41). } \\
2013\end{array}$ & $90-120$ & $300-350$ & & $*$ & $\begin{array}{l}12 \text { hours/night } \\
50 \text { consecutive } \\
\text { night }\end{array}$ & rat & $\begin{array}{c}\text { Negative effect on LH, FSH } \\
\text { and testosterone levels and } \\
\text { fertilization capacity }\end{array}$ \\
\hline $\begin{array}{l}\text { Farzadinia } \\
\text { et al(46). } \\
2016\end{array}$ & $\begin{array}{l}95,105 \\
\text { and } 115\end{array}$ & $\begin{array}{c}8000- \\
10000 \\
\text { (recorded } \\
\text { noise in } \\
\text { metal } \\
\text { workshop) }\end{array}$ & $*$ & & $\begin{array}{l}2 \text { hours/day for } \\
60 \text { consecutive } \\
\text { day }\end{array}$ & rat & $\begin{array}{l}\text { Reduction of average } \\
\text { diameter of seminiferous } \\
\text { tubules/ reduction in } \\
\text { testosterone level }\end{array}$ \\
\hline
\end{tabular}




\begin{tabular}{|c|c|c|c|c|c|c|}
\hline $\begin{array}{c}\text { Ghanbari } \\
\text { et } \\
\text { al(39).2012 }\end{array}$ & 100 & $700-5700$ & $*$ & $\begin{array}{l}8 \text { hours/day for } \\
14 \text { consecutive } \\
\text { day }\end{array}$ & Rat & $\begin{array}{c}\text { Reduction of total } \\
\text { antioxidant capacity and } \\
\text { testosterone level }\end{array}$ \\
\hline $\begin{array}{l}\text { Abdollahi } \\
\text { et al(42). } \\
2016 \\
\end{array}$ & 100 & $500-8000$ & $*$ & $\begin{array}{c}8 \text { hours/day for } \\
10 \text { consecutive } \\
\text { day }\end{array}$ & Mice & $\begin{array}{l}\text { Reduction of sperm viability } \\
\text { and sperm motility } \\
\text { (progressive and immotile) }\end{array}$ \\
\hline $\begin{array}{l}\text { Pramanik } \\
\text { et al(47). } \\
\quad 2012\end{array}$ & $\begin{array}{l}\text { Recorded } \\
\text { Traffic } \\
\text { noise }(80 \\
\text { and } 90 \mathrm{~dB})\end{array}$ & - & $*$ & $\begin{array}{c}\text { acute exposure: } \\
5 \text { hours/day for } \\
30 \text { consecutive } \\
\text { day } \\
\text { Chronic } \\
\text { exposure: } 5 \\
\text { hours/day for } 60 \\
\text { consecutive day }\end{array}$ & Rat & $\begin{array}{l}\text { Significant decrease in } \\
\text { protein level of testis/ } \\
\text { testosterone suppression }\end{array}$ \\
\hline $\begin{array}{l}\text { Ahmadi et } \\
\text { al(48). } \\
2015\end{array}$ & $\begin{array}{c}100 \\
\text { (similar to } \\
\text { traffic } \\
\text { noise) } \\
\end{array}$ & $700-5700$ & $*$ & $\begin{array}{c}1,3 \text { and } 6 \\
\text { hours/day for } 8 \\
\text { consecutive day }\end{array}$ & Rat & $\begin{array}{l}\text { Reduction of LH, FSH and } \\
\text { testosterone level }\end{array}$ \\
\hline $\begin{array}{l}\text { Chamkori } \\
\text { et al(6). } \\
2015\end{array}$ & $\begin{array}{l}107 \text { and } \\
119\end{array}$ & $\begin{array}{l}\text { workplace } \\
\text { noise }\end{array}$ & $*$ & $\begin{array}{l}8 \text { hours/ day and } \\
40 \text { hours per } \\
\text { week }\end{array}$ & Human & $\begin{array}{l}\text { Reduction of LH, FSH and } \\
\text { testosterone level in } 119 \mathrm{~dB} \\
\text { exposed noise group }\end{array}$ \\
\hline
\end{tabular}

\section{Conclusion}

The noise frequency range that can be heard by the human ear is between $20 \mathrm{~Hz}$ to $20 \mathrm{kHz}$ (49). Based on the literature review, exposure to high noise levels can play a role as a risk factor for infertility. Based on table 2, most researches, except for a small number of studies, have not focused on factors such as noise level, frequency range, and exposure time from the standpoint of industrial health; therefore focusing on the real conditions of the workplace, requires the consideration of the following items in the field of noise and fertility:

Selecting animal species: The data from table 1 can be used to select the right option for studying fertility along with features like availability, location of the tests, cheap and easy portability.

Selecting the frequency range: Among laboratory animals, mouse has the least sensitivity at frequencies below $1000 \mathrm{~Hz}$. It is better to selected a sample that have the greatest sensitivity towards the frequency range defined in the present study. Kelly et al. determined rat's hearing range between $250 \mathrm{~Hz}$ and $80 \mathrm{kHz}$ at the noise level of $70 \mathrm{~dB}(50)$. Rats are most sensitive at a frequency of $8 \mathrm{kHz}$
(50-52), thus, considering audible frequency range $(20 \mathrm{~Hz}$ to $20 \mathrm{kHz}$ ), a sample must be selected that somewhat cover the understandable frequency range. To compare the frequency range understood by laboratory samples with humans, figure 2 would be very helpful. Thin lines indicate the frequency range, which is understood by the sample at the noise level of $60 \mathrm{~dB}$ and thick lines represent a frequency range, which is understood at the noise level of $10 \mathrm{~dB}$.

Chambers for noise exposure: Considering that each animal will have its own specific requirements (such as breathing, water and food, etc.) (54). Choosing the appropriate chamber size for exposure will be very critical because the noise frequency should be distributed homogenously inside the chamber and it must be reverberant (55). None of the studies listed in table 1, except for Vosoughi et al. (40)had appropriate protocol for designing the exposure chamber. Noises produced in the chambers can be played and designed through audio recordings in the workplace or by software such as Cool Edit.

Spermatogenesis period: The best time for exposure is full duration of spermatogenesis period. According to table 1, rat is the closest animal to humans (52 days). 


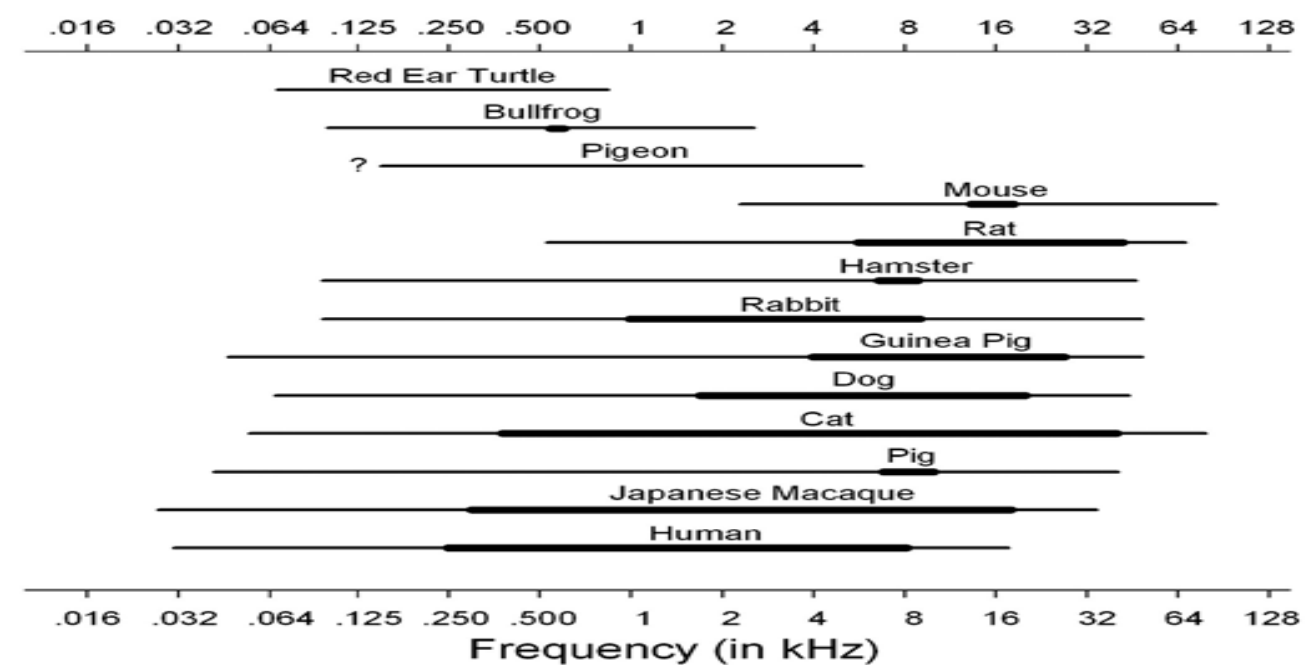

Figure 2: The hearing ranges of laboratory animals compared with those of humans(53)

The gestation period of this sample is 21 days and therefore, the effect of noise on the fetus and ultimately generational change can be determined as the female mice get pregnant by a male mice exposed to the noise. Each of males and females can be exposed to noise and its impact can be detected, but since women attend noisy environments less than men, most studies are done on males.

Exposure period: Considering that the shiftwork duration (morning / afternoon / evening) is 8 hours in Iran and most countries, and that the results of animal studies should be generalized to humans, noise exposure time of 8 hours should be chosen to eventually have higher generalization ability.

Exposure turn: Considering that humans are diurnal creatures and most of the rodents are nocturnal (54), interventional studies on rodents in diurnal turn (animal's resting time) with nocturnal turn (animal's activity time) can create differences in the results. Therefore, researchers are recommended to do the interventions in day and night and select the appropriate exposure time after conducting the necessary investigation. Table 2 reflects the fact that some studies have been done in the night and in daytime.

Occupational examination: According to the labor law, occupational examinations should be conducted on an annual basis. Moreover, people working in the industrial environments in Iran are mainly of childbearing age; therefor, it is recommended to measure the level of male sex hormone (testosterone) in the health examinations (employment, periodic examinations, etc.) because lower testosterone levels in men is considered as an infertility alarm.

Using antioxidants: An important issue that affects the sperm quality is increasing the level of reactive oxidative specious (ROS) in the sperm and semen. Increased ROS production and oxidative stress lead to lipid peroxidation of unsaturated fatty acids in sperm plasma membrane and damages sperm motility features and its chromatin structure and finally decreases sperm fertility. The production of ROS by sperm could have two different effects, which includes positive effects on carrying capacity, acrosome reaction, maintaining fertility potential and the integrity of mitochondrial inner membrane (56), and negative effects, including reduced sperm survival and sperm nucleus structural and integrity damage. The latter process is also associated with egg-sperm fertilization rate and decreased sperm motility (57). Antioxidants are compounds that protect cells against damage caused by free radicals. Noise complications on fertility can be prevented at the lowest possible cost using medical plants which are found frequently in Iran. There are a lot of antioxidants that have been used in 
different studies. These factors include vitamins E, C (41), zinc (58), selenium, and herbal medicines such as Calligonum (59), cinnamon and ginger (60-64).

In the end, it seems necessary to design and implement extensive studies by considering the actual conditions in the workplace (noise level, frequency, exposure time and etc.) so that necessary decisions could be adopted at macro level (as formulated in the guide on occupational exposure limits) after preparing a coherent database in order to provide control solutions.

\section{Acknowledgements}

The article is written based on the $\mathrm{PhD}$ thesis approved by Tarbiat Modares University. I should express my sincere gratitude to all professors and colleagues who helped me throughout this research project.

Conflict of interest: None declared.

\section{References}

1. World Health Organization. Burden of disease from environmental noise: Burden of disease from environmental noise: Quantification of healthy life years lost in Europe. Copenhagen, Denmark: World Health Organization Regional Office for Europe; 2011. Available from: http://www.euro.who.int/_data/assets/pdf_file /0008/136466/e94888.pdf

2. Passchier-Vermeer W, Passchier WF. Noise exposure and public health. Environ Health Perspect 2000; 108(Suppl 1):123-31.

3. Swami CG, Ramanathan J, Jeganath CCh. Noise exposure effect on testicular histology, morphology and on male steroidogenic hormone. Malays J Med Sci 2007; 14(2):28-35.

4. Armario A, Castellanos JM. Effect of noise stress on testosterone secretion in mice. IRCS Medical Science-Biochemistry 1984; 12(3):208-10

5. Xue L, Zhang D; Xiaokaiti·Yibulayin, Wang $\mathrm{T}$, Shou X. Effects of high frequency noise on female rat's multi-organ histology. Noise Health 2014; 16(71):213-7.

6. Chamkori A, Shariati M, Moshtaghi D, Farzadinia P. Effect of noise stress on the hormonal and semen analysis parameters in industrial worker of Bushehr, Iran. Crescent Journal of Medical and Biological Sciences 2015; 3(2):45-50.

7. Tak S, Davis RR, Calvert GM. Exposure to hazardous workplace noise and use of hearing protection devices among US workersNHANES, 1999-2004. Am J Ind Med 2009; 52(5):358-71.

8. Hammer MS, Swinburn TK, Neitzel RL. Environmental noise pollution in the United States: developing an effective public health response. Environ Health Perspect 2014; 122(2):115-9.

9. Ghotbi MR, Monazzam MR, Khanjani N, Nadri F, Bellah Fard SM. Driver exposure and environmental noise emission of Massey Ferguson 285 tractor during operations with different engine speeds and gears. Afr J Agric Res 2013; 8(8):652-9.

10. Monazzam M, Nadri F, Khanjani N, Ghotbi Ravandi MR, Nadri H, Barsam T, et al. Tractor drivers and bystanders noise exposure in different engine speeds and gears. Journal of Military Medicine 2012; 14(2):149-54.

11. Ghotbi Ravandi MR, Nadri F, Khanjani N, Ahmadian M. Occupational noise exposure among the workers of Kerman Cement Plant, 2009. Journal of Occupational Health and Epidemiology 2012; 1(1):17-23.

12. Jafari MJ, Karimi A, Haghshenas $M$. Extrapolation of experimental field study to a national occupational noise exposure standard. International Journal of Occupational Hygiene 2010; 2(2):63-8.

13. Lasheen SS, Refaat SH, EI-Nefiawy NE, AbdElgawad RM, Othman AI, Olama NKh. Developmental characteristics of rat testicular tissue and the impact of chronic noise stress exposure in the prenatal and postnatal periods. Anat Physiol 2015; doi:10.4172/2161-0940.S400 .

14. Shaha Ch, Tripathi R, Mishra DP. Male germ cell apoptosis: regulation and biology. Philosophical Transactions of the Royal Society B: Biological Sciences 2010; 365(1546):1501-15.

15. Working PK. Male reproductive toxicology: comparison of the human to animal models. Envion Health Perspect 1988; 77(3):37-44.

16. Drake RL, Vogl W, Mitchell AWM. Gray's anatomy for students. London: Elsevier/Churchill Livingstone; 2005.

17. Jones R, Lopez K. Human reproductive biology. $4^{\text {th }}$ ed. Cambridge, Massachusetts: Academic Press; 2014.

18. Hjollund NHI, Storgaard L, Ernst E, Bonde JP, Olsen $\mathrm{J}$. The relation between daily activities 
and scrotal temperature. Reprod Toxicol 2002; 16(3):209-14.

19. Griffin JE, Ojeda SR. Textbook of endocrine physiology. $5^{\text {th }}$ ed. Oxford, England: Oxford University Press; 2004.

20. Costabile R. Anatomy and physiology of the male reproductive system. $1^{\text {st }}$ ed. Cambridge, England: Cambridge University Press; 2013. Chapter 1 .

21. Dyer S, Chambers GM, de Mouzon J, Nygren KG, Zegers-Hochschild F, Mansour R, et al. International Committee for Monitoring Assisted Reproductive Technologies world report: Assisted Reproductive Technology 2008, 2009 and 2010. Hum Reprod 2016; 31(7):1588-609.

22. Yuce A, Turk G, Ceribasi S, Sonmez M, Ciftci M, Guvenc M. Effects of cinnamon (Cinnamomum zeylanicum) bark oil on testicular antioxidant values, apoptotic germ cell and sperm quality. Andrologia 2013; 45(4):248-55.

23. Vaziri MH, Sadighi Gilani MA, Kavousi A, Firoozeh M, Khani Jazani R, Taqi Dizaj AV, et al. The relationship between occupation and semen quality. Int J Ferti Steril 2011; 5(2):6671.

24. Kamali M, Baghestani AR, Kashfi F, Kashani H, Tavajohi Sh, Amirchaghmaghi E. A survey on infertility in Royan Institute. Infertility 2007; 1(1):23-6.

25. Ghahramani F, Ghaem H. The effective factors on men infertility: a case-control study. Journal of Gorgan University of Medical Sciences 2005; 7(2):42-5.

26. Vahidi S, Ardalan A, Mohammad K. Prevalence of primary infertility in the Islamic Republic of Iran in 2004-2005. Asia Pac J Public Health 2009; 21(3):287-93.

27. Zegers-Hochschild F, Adamson GD, de Mouzon J, Ishihara O, Mansour R, Nygren K, et al .International Committee for Monitoring Assisted Reproductive Technology (ICMART) and the World Health Organization (WHO) revised glossary of ART terminology, 2009. Fertil Steril 2009; 92(5):1520-4.

28. Grzanna R, Lindmark L, Frondoza CG. Ginger-an herbal medicinal product with broad anti-inflammatory actions. J Med Food 2005; 8(2):125-32.

29. Guzick DS, Overstreet JW, Factor-Litvak P, Brazil CK, Nakajima ST, Coutifaris C, et al. Sperm morphology, motility, and concentration in fertile and infertile men. $\mathrm{N}$ Engl $\mathrm{J}$ Med 2001; 345(19):1388-93.

30. Carlsen E, Giwercman A, Keiding N, Skakkebæk NE. Evidence for decreasing quality of semen during past 50 years. BMJ 1992; 305(6854):609-13.

31. Brugh VM 3rd, Lipshultz LI. Male factor infertility: evaluation and management. Med Clin North Am 2004; 88(2):367-85.

32. Pierik FH, Van Ginneken AM, Dohle GR, Vreeburg JTM, Weber RFA. The advantages of standardized evaluation of male infertility. Int J Androl 2000; 23(6):340-6.

33. Nevin CA. Effects of lifestyle and environment on human sperm. [Thesis PhD]. Manchester, England: Manchester Metropolitan University; 2016.

34. Lue Y, Sinha Hikim AP, Wang Ch, Im M, Leung A, Swerdloff RS. Testicular heat exposure enhances the suppression of spermatogenesis by testosterone in rats: the "Two-Hit" approach to male contraceptive development. Endocrinology 2000; 141(4):1414-24.

35. Paranagama PA, Wimalasena S, Jayatilake GS, Jayawardena AL, Senanayake UM, Mubarak AM. A comparison of essential oil constituents of bark, leaf, root and fruit of cinnamon (Cinnamomum zeylanicum Blum) grown in Sri Lanka. J Natl Sci Found 2001; 29(3-4):147-53.

36. Diab AA, Hendawy A, Asala AK, Ibrahim SS, Hassan MA. Effect of noise stress on pituitary gonadal axis in albino rats. J Am Sci 2012; 8(11):198-202.

37. Jalali M, Saki Gh, Sarkaki AR, Karami K, Nasri S. Effect of noise stress on count, progressive and non-progressive sperm motility, body and genital organ weights of adult male rats. J Hum Reprod Sci 2012; 5(1):48-51.

38. Ruffoli R, Carpi A, Giambelluca MA, Grasso L, Scavuzzo MC, Giannessi FF. Diazepam administration prevents testosterone decrease and lipofuscin accumulation in testis of mouse exposed to chronic noise stress. Andrologia 2006; 38(5):159-65.

39. Ghanbari M, Mortazavi SB, Khavanin A, Khazaei M. Simultaneous effects of exposure to microwaves and noise on male rat'sperm parameters and total antioxidant capacity. Health Scope 2013; 1(4):179-85.

40. Vosoughi Sh, Khavanin A, Salehnia M, Asilian Mahabadi H, Soleimanian A. Effects of simultaneous exposure to formaldehyde vapor and noise on mouse testicular tissue and sperm parameters. Health Scope 2012; 1(3):110-7.

41. Saki G, Jasemi M, Sarkaki AR, Fathollahi A. Effect of administration of vitamins $\mathrm{C}$ and $\mathrm{E}$ on fertilization capacity of rats exposed to noise stress. Noise Health 2013; 15(64):194-8. 
42. Abdollahi MB, Khavanin A, Vosoughi S, Amanpour S, Kaydani M, Noorloie S. The effects of noise exposure on sperm parameters (count, motility and viability) mice. Journal of Acoustical Engineering Society of Iran 2015; 3(1):66-72.

43. Fathollahi A, Jasemi M, Saki G. Effect of noise stress on male rat fertility, and the protective effect of vitamins $\mathrm{C}$ and $\mathrm{E}$ on its potential effect. Arab J Urol 2013; 11(1):101-5.

44. Kenani M, Rajabzadeh A, Saki Gh, Khodadadi A, Sarkaki Al, Jafai A, et al. A survey of the relationship between noised pollution, honey and vitamin E and plasma level of blood sexual hormones in noise-exposed rats. Jentashapir Journal of Health Research 2015; 6(1):e27331. doi: 10.5812/jjhr.27331

45. Mohamed AF, Hanafy SM, Mahmoud A. The possible protective effect of black seed (Nigella Sativa) oil on the testes of adult male albino rat exposed to noise. Journal of Histology \& Histopathology 2015; 2(21). doi:http://dx.doi.org/10.7243/2055-091X-2-21

46. Farzadinia P, Bigdeli M, Akbarzadeh S, Mohammadi M, Daneshi A, Bargahi A. Effect of noise pollution on testicular tissue and hormonal assessment in rat. Andrologia 2016; 48(9):869-73.

47. Pramanik P, Biswas S. Traffic noise: a silent killer of male gamete of albino rats. Al Ameen Journal of Medical Sciences 2012; 5(1):82-9.

48. Ahmadi R, Gohari A, Hooshmand M. The effect of noise stress on serum levels of $\mathrm{LH}$, FSH and testosterone in male rats. Feyz Journal of Kashan University of Medical Sciences 2015; 19(1):24-9.

49. South T. Managing noise and vibration at work: a practical guide to assessment, measurement and control. $1^{\text {st }}$ ed. Oxford, United Kingdom: Elsevier ButterworthHeinemann; 2004.

50. Kelly JB, Masterton B. Auditory sensitivity of the albino rat. J Comp Physiol Psychol 1977; 91(4):930-6.

51. Campo P, Pouyatos B, Lataye R, Morel G. Is the aged rat ear more susceptible to noise or styrene damage than the young ear? Noise Health 2003; 5(19):1-18.

52. Lataye R, Campo P, Loquet G. Combined effects of noise and styrene exposure on hearing function in the rat. Hear Res 2000; 139(1-2):86-96.
53. Heffner HE, Heffner RS. Hearing ranges of laboratory animals. J Am Assoc Lab Anim Sci 2007; 46(1):20-2.

54. Shayne CG. Animal models in toxicology. $2^{\text {nd }}$ ed. Boca Raton, Florida, United States: CRC Press, Taylor \& Francis Group; 2006.

55. Cobo P, Murillo-Cuesta S, Cediel R, Moreno A, Lorenzo-García P, Varela-Nieto I. Design of a reverberant chamber for noise exposure experiments with small animals. Appl Acoust 2009; 70(8):1034-40.

56. Alvarez JG, Storey BT. Differential incorporation of fatty acids into and peroxidative loss of fatty acids from phospholipids of human spermatozoa. Mol Reprod Dev 1995; 42(3):334-46.

57. Sikka SC. Oxidative stress and role of antioxidants in normal and abnormal sperm function. Front Biosci 1996; 1:e78-86.

58. Saki G, Jalali MA, Sarkaki AR, Karami K, Ahangarpoor A. Effect of supplementation of zinc on fertilization capacity of male rats exposed to noise stress. International Journal of Pharmaceutical Research and Allied Sciences 2016; 5(2):67-74.

59. Asgari Jahromi M, Movahedin M, Amanloo M, Mowla SJ, Mazaheri Z. The effects of calligonum extract on sperm parameters and the rate of apoptosis in aged male mice testis issue. Modares Journal of Medical Sciences: Pathobiology 2013; 16(1):41-54.

60. Hafez DA. Effect of extracts of ginger goots and cinnamon bark on fertility of male diabetic rats. J Am Sci 2010; 6(10):940-7.

61. Joshi K, Awte Sh, Bhatnagar P, Walunj S, Gupta R, Joshi SP, et al. Cinnamomum zeylanicum extract inhibits proinflammatory cytokine TNF: in vitro and in vivo studies. Research In Pharmaceutical Biotechnology 2010; 2(2):14-21.

62. Khaki A. Effect of Cinnamomum zeylanicumon on Spermatogenesis. Iran Red Crescent Med J 2015; 17(2):e18668.

63. Khaki A, Khaki AA, Hajhosseini L, Sadeghpour Golzar F, Ainehchi N. The antioxidant effects of ginger and cinnamon on spermatogenesis dys-function of diabetes rats. Afr J Tradit Complement Altern Med 2014; 11(4):1-8.

64. Mahmoudi MN, Hejazi S, Afshari F. The effect of hydroalcoholic extract of cinnamon on mice testis tissue. Biol Forum 2015; 7(1):1461-8. 